\title{
Wykorzystanie sieci neuronowych do analizy danych i pozyskiwania wiedzy w systemie ekspertowym do oceny parametrów benzyn silnikowych
}

\begin{abstract}
W pracy przedstawiono możliwość wykorzystania sieci neuronowych do analizy danych i tworzenia struktur mogących samodzielnie przetwarzać dane. Rozważania oparto na przykładzie systemów zdolnych do interpretowania zależności pomiędzy składem chromatograficznym benzyny silnikowej a wielkościami opisującymi jej nieaddytywne parametry jakościowe (LOM, LOB, DVPE, E70, E100). Przeprowadzone badania wskazują, że modele opracowane na bazie sieci neuronowych także w tym przypadku sprawdzają się jako dobre narzędzie predykcyjne i mogą być podstawą do tworzenia systemów ekspertowych. Te systemy natomiast mogą w przyszłości stać się ważnym elementem w strukturach kognitywnych wspomagających zarządzanie procesem produkcji paliw w warunkach czasu rzeczywistego.
\end{abstract}

Słowa kluczowe: sieci neuronowe, sztuczna inteligencja, predykcja nieaddytywnych właściwości benzyn, systemy ekspertowe.

\section{The use of neural networks for data analysis and knowledge acquisition in an expert system designed to evaluate parameters of motor gasoline}

\begin{abstract}
The paper presents the possibility of using neural networks to analyze data and create structures which can independently process the data. Considerations based on the example of systems capable of interpreting the relationship between the individual chromatographic composition of motor gasoline and non-additive values that describe its quality parameters (RON, MON, DVPE, E70, E100). The study indicates that the models developed based on neural networks are suited predictive tools in this case as well and can be the basis of expert systems. In turn, these expert systems have the potential to become an important element in the cognitive structure of management support fuel production process in real-time conditions.
\end{abstract}

Key words: neural networks, artificial intelligence, prediction of non-additive gasoline properties, expert systems.

\section{Wprowadzenie}

Współczesne życie gospodarcze stawia przed inżynierami i osobami zarządzającymi przedsiębiorstwami coraz trudniejsze zadania. Wymagają one dostępu do coraz większych ilości aktualnych i dobrze dobranych informacji, które w większości nie są dostępne wprost, ale mogą być zdobyte między innymi dzięki odpowiedniemu zastosowaniu technik sztucznej inteligencji. Tylko w ten sposób można bowiem rozwiązać problem narastającej luki informacyjnej - różnicy pomiędzy informacją dostępną a informacją potrzebną w procesie decyzyjnym (rysunek 1). 


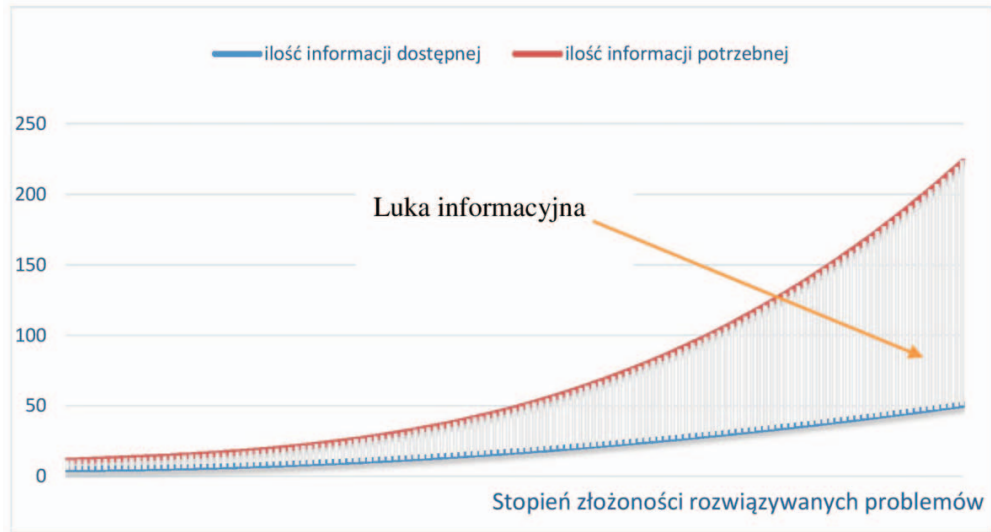

Rys. 1. Problem luki informacyjnej

Jednocześnie systemy nadzorcze ${ }^{1}$, działające w wielu procesach przemysłowych, mogą gromadzić dane, które później, odpowiednio przetworzone, stają się źródłem informacji dla inżynierów wiedzy współtworzących zaawansowane narzędzia informatyczne wspomagające zarządzanie, takie jak systemy ekspertowe.

Cyfrowe gromadzenie i przetwarzanie danych zdecydowanie ułatwia pracę, ale przestaje wystarczać wówczas, gdy informacje wejściowe, na podstawie których należy podjąć decyzję, mają wartość bliską krytycznej lub są niepewne, a zależności między nimi są nie do końca określone. Jest to szczególnie kłopotliwe, gdy jednocześnie pozostaje krótki czas na podjęcie decyzji, a decyzje te mają doniosłe skutki, często o znaczeniu strategicznym dla całego przedsiębiorstwa.
Dodatkowa trudność zachodzi, gdy w trakcie optymalizacji pojawiają się nowe czynniki warunkujące proces sterowania, związane z przerobem surowców o zmiennym składzie, czy czynniki wynikające ze zmieniającej się okresowo proporcji składników, związanej z niedoborem któregoś z nich, przy jednoczesnej niemożliwości uzupełnienia braków. Na tym etapie samo gromadzenie danych i ich analiza nie wystarcza. Niedostateczne są w tym przypadku także typowe narzędzia analityczne, pozwalające na śledzenie związków między danymi i obserwowanie trendów. Sygnalizowany tu problem narasta wówczas, gdy zależności pomiędzy składnikami produktu gotowego są nieliniowe i pojawiają się „bonusy” (wartości addytywne) o ujemnej lub dodatniej wartości - trudne do dokładnego przewidzenia. $\mathrm{W}$ tych warunkach rodzi się problem niebezpieczeństwa wytworzenia produktu gotowego, który może nie spełniać specyfikacji jakościowej, co naraża przedsiębiorstwo na potencjalnie wysokie straty finansowe i wizerunkowe. Zastosowanie jako remedium prostego rozwiązania nadmiarowego może powodować marnowanie środków i w efekcie uczynić produkcję nieopłacalną, co w dalszej perspektywie może grozić utratą rynku zbytu. W omawianych przypadkach przydatność standardowych rozwiązań nowoczesnej informatyki gospodarczej (rysunek 2) w postaci systemów analitycznych OLAP czy systemów wspomagania decyzji DSS jest ograniczona.

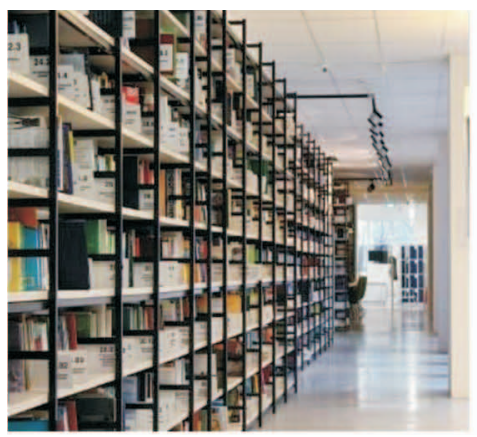

Zewnętrzne źródło danych

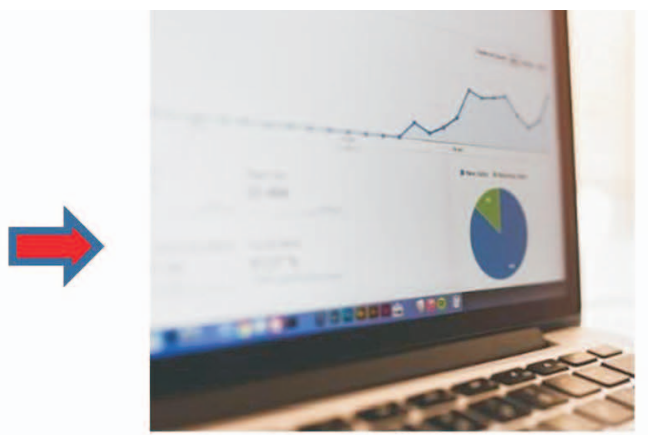

Komputerowa analiza i przetwarzanie danych

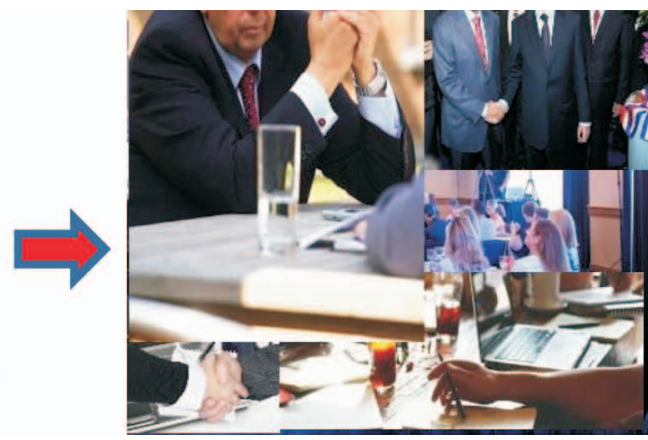

Podejmowanie decyzji i zarządzanie na podstawie przeanalizowanych danych

Rys. 2. Typowe zastosowania komputerów w systemach wspomagania decyzji

Ten problem występuje między innymi wówczas, gdy na bieżąco (on line) należy optymalizować dynamiczny proces technologiczny - na przykład rozważane w tej pracy procesy rafineryjne i proces produkcji paliwa.

\footnotetext{
${ }^{1}$ Mowa o systemach SCADA, DCS itp.
}

Dla sprostania rodzącym się zadaniom potrzeba czegoś więcej niż narzędzia informatyczne do gromadzenia danych i ich statystycznej obróbki. Zachodzi konieczność wbudowania w systemy informatyczne ,inteligencji”, która bez udziału człowieka zareaguje na nowe, nieznane sytuacje (rysunek 3).

$\mathrm{W}$ tym artykule jest mowa o sposobie tworzenia takiej inteligencji. 


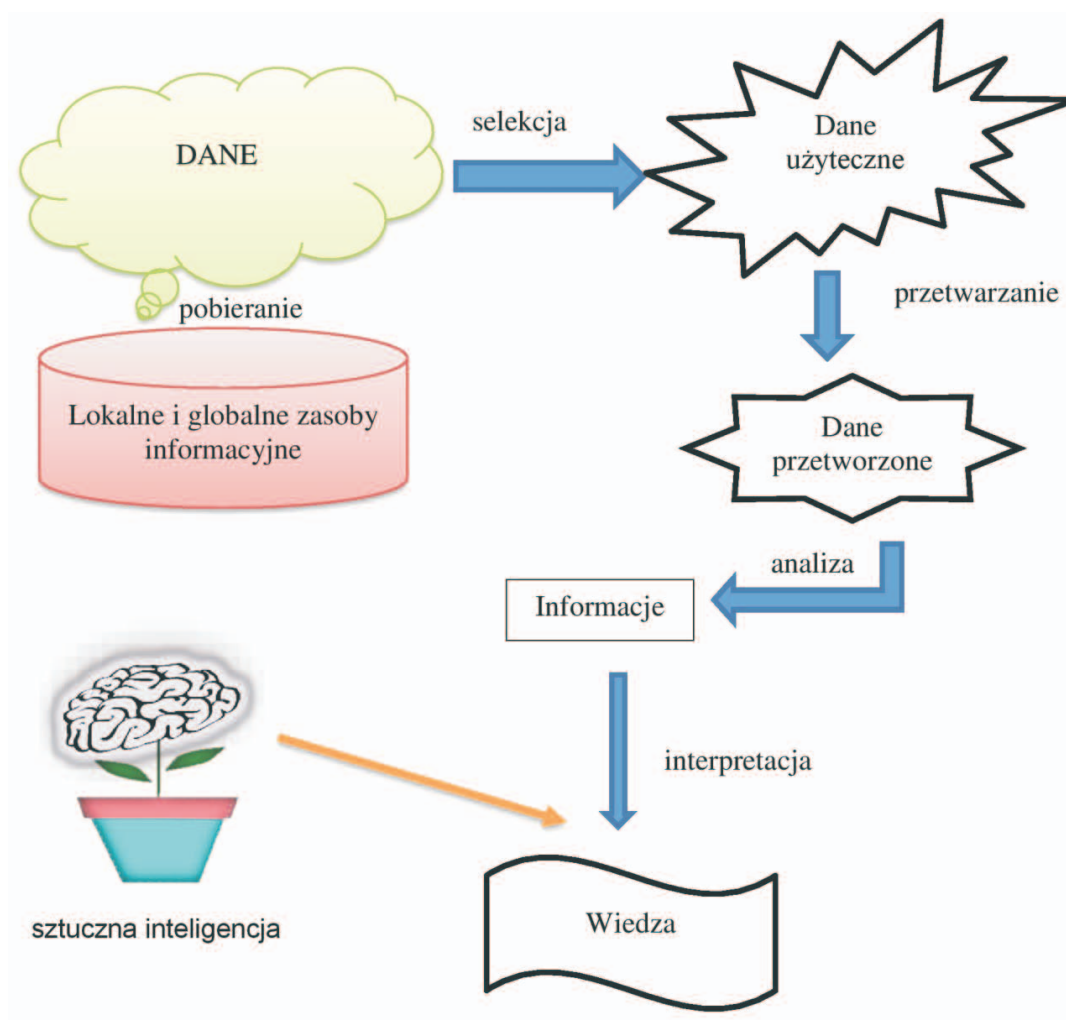

Rys. 3. Sztuczna inteligencja i jej miejsce w systemie informacyjnym

\section{Systemy ekspertowe}

W aktualnie używanych, standardowych systemach informatycznych gromadzi się i przekształca na ogół nieuporządkowane i nieustrukturyzowane dane. Dzięki pracy komputerów wyposażonych w odpowiednie programy przetwarzania $i$ analizy tych danych przerabia się je na informacje przydatne, czytelne i łatwo interpretowalne dla człowieka. Jednak w typowych przypadkach dopiero człowiek dokonuje konwersji tych informacji w wiedzę, zaś zamiana wiedzy na mądrość (konieczną do wyboru trafnej strategii) wymaga często takiej intuicji i inteligencji, którą posiada niewielu (rysunek 3).

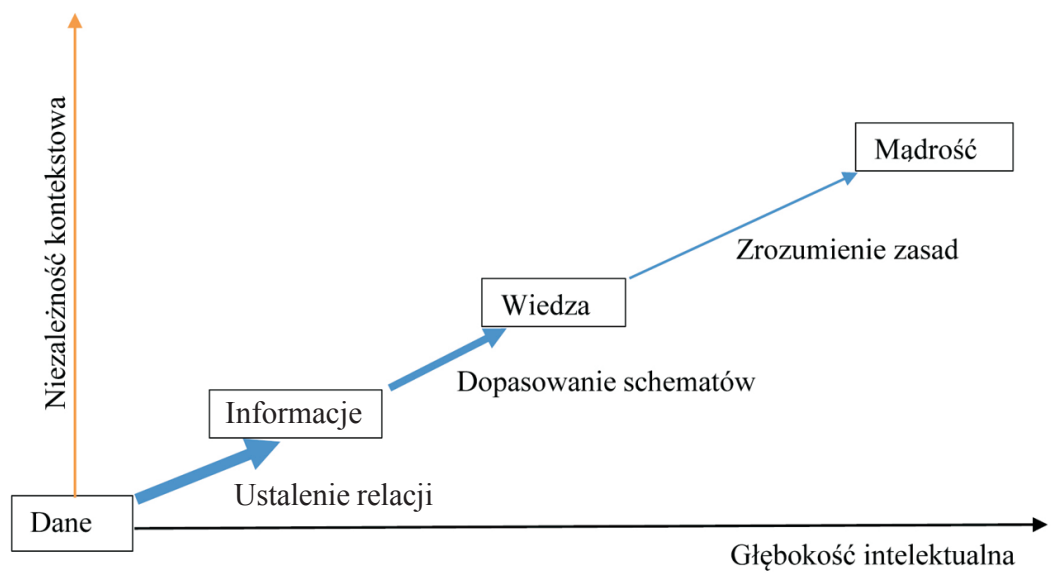

Rys. 4. Sekwencja przekształceń wiodących od danych do mądrości
W awangardowych badaniach współczesnej informatyki próbuje się pokonywać te ograniczenia i dostarczać zainteresowanym narzędzia informatyczne adekwatne do ich zadań. Jednym z częściej używanych narzędzi sztucznej inteligencji są systemy ekspertowe [1], oparte na podanych wyżej założeniach. Są one doskonalone od wielu lat i zaczynają wykazywać coraz więcej cech, które odróżniają je od klasycznych systemów wspomagających decyzje i przybliżają do czegoś, co można już nazwać sztuczną inteligencją. Układy takie wykazują zdolność automatycznego wnioskowania, uczenia się i uogólniania wiedzy, a także umiejętność kategoryzacji i rozpoznawania danego obiektu $\mathrm{w}$ dowolnym kontekście. Podstawowy cel takich systemów to samodzielne wypracowanie trafnej decyzji dostosowanej do zaistniałej sytuacji, a następnie jej wdrożenie lub przekazanie człowiekowi do zatwierdzenia.

Celem twórców systemów ekspertowych jest osiągnięcie przez program komputerowy takiej biegłości, aby mógł on robić to samo co ekspert posiadający wiedzę praktyczną i teoretyczną zdobytą przez długoletnie i staranne badanie danej dziedziny nauki. Twórcy tych systemów - inżynierowie wiedzy - „napełniają” powstający system wiedzą pozyskaną od ekspertów - ludzi. 
Oczywiście jest to wiedza odpowiednio przygotowana, przetworzona i spreparowana, bo sposób reprezentacji wiedzy ludzi w systemach komputerowych to całkiem poważny i nie do końca jeszcze rozwiązany problem naukowy. Dodatkowo wiedza dla systemu ekspertowego może być pozyskiwana z innych źródeł - ogólnie dostępnych lub unikatowych, stanowiących własność intelektualną wykorzystującej system ekspertowy osoby lub firmy. Efektem tych działań jest stworzenie systemu, który odciąży lub zastąpi eksperta. Użycie takiego systemu będzie celowe, gdy ekspert będzie nieosiągalny, zajęty innymi zadaniami lub gdy koszty jego zatrudnienia okażą się zbyt wysokie. Wykorzystanie systemu będzie w szczególności celowe, gdy użytkownik znajdzie się w posiadaniu zbyt rozległych lub niezrozumiałych dla niego informacji, w których prawidłowej interpretacji system ekspertowy może mu znacząco pomóc.

Na podstawie badań aplikacyjnych stwierdzono, że użytkownicy oceniający przydatność systemów ekspertowych zwracali uwagę na następujące cechy systemu:

- szybkie i bezbłędne rozwiązywanie postawionych problemów (poprawność systemu),

- umiejętność szybkiego rozwiązywania podobnych zadań,

- możliwość doboru stopnia komplikacji systemu, związana z dziedziną wiedzy i możliwościami psychofizycznymi osoby użytkującej ten system,

- umiejętność objaśniania przez system powodów przyjęcia takiego lub innego rozwiązania problemu,

- brak konieczności zastanawiania się przez użytkownika nad celowością przyjętych założeń czy sposobem dochodzenia do odpowiedzi systemu na postawione pytanie czy problem, ale w razie potrzeby możliwość szczegółowego poznania wszystkich uwarunkowań,

- stopniowe (a nie skokowe) pogarszanie się jakości pracy systemu, gdy postawiony problem wymyka się regułom zawartym w systemie (uniwersalność wewnątrz zawartości wiedzy w systemie).

Warto jeszcze raz podkreślić, że typowy użytkownik systemu ekspertowego może nie zajmować się szczegółami procesu poszukiwania odpowiedzi, bo to zadanie powierzone jest automatycznemu systemowi wnioskującemu wbudowanemu w system ekspertowy, jak to przedstawiono na rysunku 5. Rysunek ten podkreśla również fakt, że system ekspertowy wyposażony jest $w$ interfejs naturalny, pozwalający zawsze spieszącym się użytkownikom na formułowanie zapytań w sposób dla nich maksymalnie wygodny - to znaczy w języku naturalnym - oraz dający możliwości wyrażania odpowiedzi także w tym języku, co znacząco ułatwia ich interpretację i wykorzystanie.

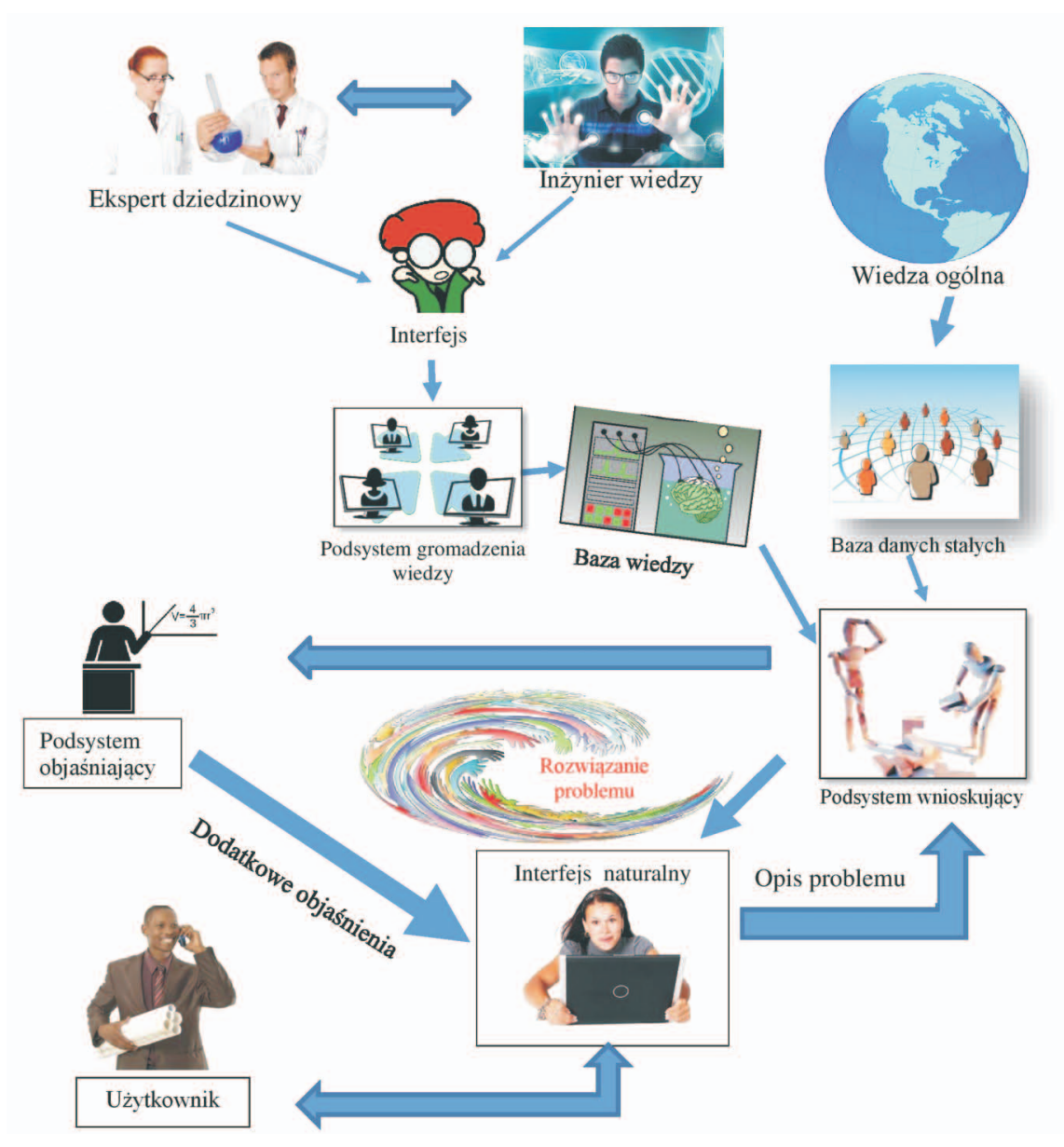

Rys. 5. Ogólna struktura systemu ekspertowego

Ogólnie można stwierdzić, że systemy ekspertowe powinny być użyteczne (łatwe w komunikacji i skuteczne w tym, do czego są przeznaczone), powinny wykazywać się konsekwencją $\mathrm{w}$ działaniu oraz poprawnie wyprowadzać uzasadnione logicznie wnioski - nawet w warunkach niepewności. Jest to szczególnie ważne w przypadku systemów ekspertowych czasu rzeczywistego ${ }^{2}$; jakość i szybkość reakcji takiego systemu powinna być lepsza od reakcji człowieka. Decydent wspomagany przez system ekspertowy może w efekcie podejmować decyzje szybciej i przy mniejszym poziomie ryzyka. To uzasadnia celowość

\footnotetext{
${ }^{2} \mathrm{~Np}$. systemy naprowadzania, nadzorowania pracy elektrowni jądrowych, monitorowanie procesów produkcyjnych, niektóre operacje giełdowe itp.
} 
wykorzystania takiego systemu w wielu zastosowaniach, oczywiście przy założeniu, że jest on poprawnie zbudowany i dokładnie przetestowany, trzeba bowiem zdawać sobie sprawę z tego, że w systemie ekspertowym czasu rzeczywistego obsługujący go personel może nie mieć możliwości naprawy ewentualnego błędu.

\section{Potencjalne korzyści ze stosowania systemów ekspertowych oraz trudności w pozyskiwaniu dla nich wiedzy}

System ekspertowy działa na podstawie wiedzy zawartej w jego bazie. Twórca systemu musi zapewnić taką jej reprezentację, żeby baza ta zawierała nie tylko konkretne fakty i informacje, ale także reguły i zasady, zgodnie z którymi możliwe jest prowadzenie automatycznego wnioskowania. Kompletna baza wiedzy i możliwość jej rozszerzania o nowe fakty i reguły wnioskowania stanowią podstawę właściwego działania systemu. Akwizycja wiedzy jest ściśle związana z procesem jej reprezentacji, szczególnie w przypadku wiedzy niepewnej, niekompletnej czy nieformalnej (zdroworozsądkowej). Zazwyczaj, przy wybraniu nieodpowiedniej formy reprezentacji wiedzy, ta wiedza, która została pozyskana i skutecznie wprowadzona do bazy wiedzy, jest tylko podzbiorem wiedzy eksperta. Jej treść i forma to wypadkowa procesu artykulacji wiadomości przez eksperta, zrozumienia ich przez inżyniera wiedzy i jego zdolności implementacji tej wiedzy w bazie wiedzy (patrz górna część rysunku 4). Oczywiście dla systemów ekspertowych najbardziej cenna jest wiedza kompletna i pewna. Stąd najlepszym rozwiązaniem byłoby, aby ekspert posiadł umiejętności inżyniera wiedzy i sam przekazywał swoją wiedzę do bazy wiedzy. Jednak nawet w przypadku osiągnięcia tego celu nadal nie ma pewności, że wiedzę wprowadzono do systemu i odwzorowano w nim całkowicie poprawnie [1].

Obok obiektywnych, wymienionych wyżej, przeszkód utrudniających uzyskanie dobrej jakości wiedzy do wykorzystania w systemie ekspertowym występują także przeszkody subiektywne.

W rzeczywistych warunkach wiedza, jaką posiadają eksperci, jako unikatowa i niedostępna dla ogółu, często jest źródłem ich utrzymania lub źródłem dodatkowych przychodów. Wiedza ta przekazana systemowi ekspertowemu staje się wiedzą powszechną i jak każdy towar łatwo dostępny - traci na wartości. Można powiedzieć, że jej wartość pieniężna dewaluuje się. System wydaje wiele ekspertyz za mniejsze pieniądze, a ekspert staje się „niepotrzebny” - do pierwszego poważnego błędu systemu lub do chwili napotkania problemu nierozwiązywalnego przez system. Generalnie zasilenie wiedzą systemu ekspertowego zdecydowanie zmniejsza szansę zarobku eksperta - co niekoniecznie dobrze nastawia go do całego przedsięwzięcia. Problem ten jest istotny zwłaszcza w przypadku mniej kreatywnych ekspertów, którzy boją się zbyt „mądrych” systemów, mogących odebrać im pracę (przy jednocześnie małej liczbie zapaleńców dzielących się swoją wiedzą za darmo). Dlatego istnieje niebezpieczeństwo, że na poziomie pozyskiwania wiedzy mogą pojawić się dodatkowe przekłamania w interpretacji danych, zwłaszcza tych, które przed wprowadzeniem do bazy danych wymagają interpretacji człowieka. Może pojawić się „szum”, który skutecznie uniemożliwi bezbłędne działanie systemu i już na etapie wdrażania może skutecznie zniechęcić potencjalnych użytkowników do jego stosowania.

W takich przypadkach może nie sprawdzić się „,manualny" sposób nabywania wiedzy przez system, gdy inżynier wiedzy wprowadza do systemu (komputera) dane pochodzące od człowieka eksperta (relacja: ekspert-inżynier wie$d z y$-baza wiedzy). Z kolei relacja człowiek (ekspert) - komputer, gdy ekspert sam wprowadza wiedzę do szkieletowego systemu komputerowego wyposażonego w moduł pozyskiwania wiedzy (półautomatyczne nabywanie wiedzy przez system), sprawdzi się jedynie wówczas, kiedy ekspert będzie chciał używać zdeponowanej w systemie wiedzy także dla własnych celów. To ostatnie stanie się możliwe, gdy ekspert będzie wystarczająco znał możliwości systemu, a w perspektywie dostrzeże ewidentne własne korzyści z zastosowania zaproponowanego mu rozwiązania.

Mając powyższe na uwadze, należy przypuszczać, że „ręcznie” wypełniane wiedzą systemy ekspertowe mogą niekiedy nie zdawać egzaminu. Znacznie większe możliwości rozwoju i rozpowszechnienia będą miały więc systemy potrafiące samodzielnie (automatycznie) - przy znikomym udziale eksperta - tworzyć bazę wiedzy na podstawie „surowych" danych pochodzących od maszyn. Wykorzystanie metod sztucznej inteligencji umiejących wydzielić z analizowanego zbioru danych istotne informacje semantyczne pozwalające na ich znaczeniową interpretację, czyli pełne rozumienie, umożliwi prawidłowe wnioskowanie na podstawie zebranych zbiorów danych. Ponadto w miarę zdobywania doświadczenia system powinien umieć zweryfikować jakość analizowanych danych bez pomocy eksperta. Spośród wielu możliwych zastosowań powyższych rozwiązań, np. w przypadku przemysłu rafineryjnego (paliwowego) dzięki zastosowaniu systemu ekspertowego można by minimalizować koszty związane z przechowywaniem resztek, odpadów 
lub niepotrzebnych czy niezbywalnych w danym momencie półproduktów ${ }^{3}$. Taka wspomagana przez system ekspertowy optymalizacja kosztów jest istotnym składnikiem w aktualnie preferowanym bezodpadowym sposobie prowadzenia produkcji zakładów przemysłowych - zwłaszcza wówczas, gdy nieprzemyślane do końca posunięcia (metoda prób i błędów na instalacjach przemysłowych) mogą prowadzić do zakłóceń procesów technologicznych, a w konsekwencji do pojawienia się strat zamiast spodziewanych zysków.
W celu skutecznego zastosowania systemu ekspertowego w rozważanym zadaniu konieczne jest jednak zdobycie wiedzy, w którą się go wyposaży. Pozyskiwanie tej wiedzy od ludzi, którzy są ekspertami w rozważanej dziedzinie, napotyka na opisane wyżej trudności. Dlatego koncepcja, którą sugeruje się w niniejszej pracy, polega na zdobyciu potrzebnej wiedzy w sposób automatyczny poprzez uczącą się sieć neuronową, a następnie na przeniesieniu tej wiedzy do systemu ekspertowego.

\section{Sieci neuronowe jako narzędzie analizy danych i pozyskiwania wiedzy}

Zaletą sieci neuronowych jest ich zdolność do uczenia się, a w jego trakcie umiejętność samodzielnego zdobywania informacji i wiedzy również wówczas, gdy ich potencjalny użytkownik nie wie, jak rozwiązać dany problem. Sieci neuronowe wykazują zdolność do analizy zgromadzonych danych, potrafią klasyfikować i rozpoznawać różne obiekty w różnych warunkach. Istnieją liczne przykłady praktycznych zastosowań tego rodzaju sieci w wielu dziedzinach nauki do rozwiązywania różnorodnych problemów, jak również liczne opisy możliwości obliczeniowych sieci neuronowych przedstawione w setkach artykułów naukowych, książkach, doniesieniach konferencyjnych itd. [2,3]. Ze względu na potencjalne możliwości sieci neuronowych stale rośnie liczba zainteresowanych ich użytkowaniem.

Poniżej zaprezentowano przykład wykorzystania sieci neuronowych do analizy danych i pozyskiwania wiedzy $\mathrm{z}$ danych pochodzących z badania składu chemicznego benzyn metodą chromatograficzną, uzupełnionych o dane pochodzące $\mathrm{z}$ badań jakościowych.

Przedstawiony system wykorzystujący sieci neuronowe może prowadzić analizę danych na podstawie wyników badań podstawowych parametrów charakteryzujących jakość benzyny silnikowej i jej skład chemiczny.

Parametry opisujące jakość benzyny silnikowej (ilościo$w^{4}$ zmienne zależne):

- LOM - motorowa liczba oktanowa,

- LOB - badawcza liczba oktanowa,

- DVPE - prężność par benzyny oznaczona metodą Reida,

- E70 - procent oddestylowania benzyny do $70^{\circ} \mathrm{C}$,

- E100 - procent oddestylowania benzyny do $100^{\circ} \mathrm{C}$.

${ }^{3}$ Każdy zakład produkujący produkty ropopochodne posiada ograniczoną liczbę zbiorników magazynowych, w których można przechowywać półprodukty lub odpady produkcyjne, ponadto przechowywanie wiąże się ze stratami produktów oraz z utratą ich jakości i kosztami związanymi z przechowywaniem.

${ }^{4}$ Ilościowe w sensie terminologii dotyczącej zmiennych opisywanych w programie Statistica.
Parametry opisujące jakość benzyny (ilościowe zmienne niezależne):

- skład chemiczny oznaczony metodą chromatografii lub chromatogram będący podstawą do obliczenia składu chemicznego badanych benzyn silnikowych (czas retencji i udział powierzchni piku w sumie powierzchni wszystkich pików obserwowanych na chromatogramie),

- zawartość związków tlenowych (alkohole i etery),

- istnieje możliwość rozszerzenia o inne dane, np. zawartość olefin itd.

Na postawie analizy dostarczonych do sieci danych sieć dokona analizy zależności występujących pomiędzy danymi wejściowymi, np. składem chemicznym (oznaczonym metodą chromatograficzną) benzyny silnikowej, a oczekiwanym parametrem charakteryzującym jakość paliwa, np. LOM, LOB, E70, E100 lub DVPE.

Podobną analizę można wykonać, pomijając pośrednictwo człowieka (eksperta) dokonującego interpretacji danych zawartych na chromatogramie (czasy retencji, pola powierzchni pików, błędy i przesunięcia pików związanych z wzajemnym nałożeniem się pików), wprowadzając do systemu odpowiednio przygotowane, przetworzone według algorytmu interpretującego chromatogram dane surowe lub nieprzetworzone dane odwzorowujące skład chemiczny benzyny silnikowej, obrazowany przez chromatogram, a w szczególności przez pola powierzchni pików i czasy retencji odpowiadające ich maksimom.

Właśnie tego rodzaju rozwiązanie przetestowano dla 200 przypadkowych benzyn, pozyskanych z różnych stacji paliw w Polsce, dla których oznaczono: LOB, LOM, DVPE, E70, E100 i zarejestrowano charakterystyczne dla nich chromatogramy będące podstawą do określenia składu chromatograficznego benzyn. Rejestrację chromatogramów benzyn silnikowych wykonywano zgodnie z normą ASTM D5134 i każdorazowo wykorzystywano ten sam chromatograf GC wyposażony w kolumnę kapilarną firmy Petrocol o następujących parametrach:

- długość $100 \mathrm{~m}$, 


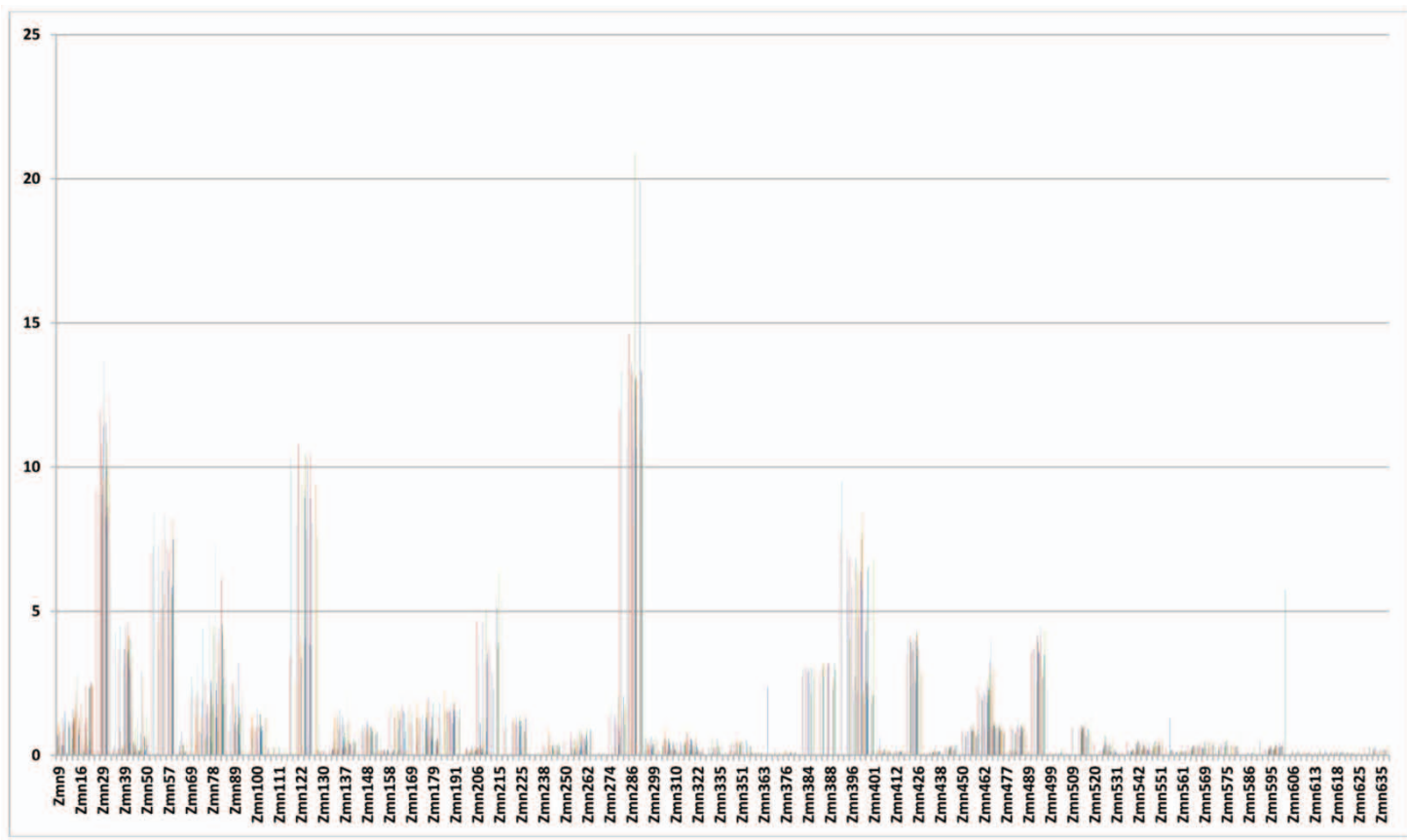

Wykres 1. Przykładowy zbiór danych wejściowych dla sieci neuronowych (widok 2D) Dane dostepne na http://bogdanhaduch.cba.pl/bhneuron1-2015.pdf wszystkich pików wyrażony w procentach jest mniejszy od $0,05 \%$. Następnie otrzymane chromatogramy ${ }^{6}$ poddano procesowi scalania przy wykorzystaniu możliwości programu Statistica. Jako zmienną zgodną w poszczególnych łączonych plikach (chromatogramach) przyjęto czas retencji, gdzie najmniejsza rozróżnialna działka pomiędzy pikami była nie mniejsza niż 0,1 minuty.
- średnica wewnętrzna $0,25 \mathrm{~mm}$,

- grubość filmu wewnętrznego $0,5 \mu \mathrm{m}$.

Wszystkie badania prowadzono w takich samych warunkach analizy:

- temp. dozownika $220^{\circ} \mathrm{C}$, temp. detektora $220^{\circ} \mathrm{C}$,

- zakres temperatur $40 \div 200^{\circ} \mathrm{C}$,

- izoterma z 5 min $\mathrm{w} 40^{\circ} \mathrm{C}$, przyrost temperatury $2^{\circ} \mathrm{C} / \mathrm{min}$ do $200^{\circ} \mathrm{C}$.

Opisany wyżej zbiór danych wejściowych przedstawiono schematycznie na wykresie 1.

$\mathrm{Na}$ wykresie tym zaznaczono rozmieszczenie na osi czasu poszczególnych pików - ich wysokość jest proporcjonalna do udziału procentowego poszczególnych węglowodorów w badanej próbce benzyny silnikowej ${ }^{5}$. Kolejnym chromatogramom przydzielano różne kolory, odpowiadające kolejnym próbkom analizowanych benzyn. Można tu zauważyć skupienie pików wokół miejsc charakterystycznych dla poszczególnych mieszanek benzynowych. Niedokładność nałożenia pików na siebie może być skutkiem błędów pomiarowych, może to być również spowodowane różnym składem badanych benzyn. Różna wysokość pików wskazuje na różny udział poszczególnych węglowodorów w badanych mieszankach benzynowych.

Ze zbioru widm (chromatogramów), których przykłady pokazano na wykresie 1 , usunięto uprzednio sygnały, dla których stosunek powierzchni piku do sumy powierzchni

\footnotetext{
${ }^{5}$ Ze względu na trudność czytelnego przedstawienia chromatogramu zastosowano schematyczny wykres słupkowy.
}

Kolejną operacją zmniejszającą liczbę zmiennych ${ }^{7}$ było dodanie do siebie sąsiadujących zmiennych (opisanych na wykresie 1), dla których przyrost czasu retencji nie przekraczał 0,1 minuty.

Tak przygotowane dane poddano obróbce wstępnej (preprocessing) przy pomocy oprogramowania firmy Statsoft dostępnego w pakiecie Statistica.

Najpierw wybrano zmienne wyjściowe i wejściowe, po czym zbiór danych podzielono na trzy części, mianowicie wydzielono z niego próbki testowe i walidacyjne, których zadaniem było sprawdzenie poprawności działania wybranych modeli rozwiązań, a resztę danych zaliczono do tak zwanego zbioru uczącego (służącego bezpośrednio do uczenia sieci). Przyjęto następujące proporcje: na część uczącą przeznaczono $70 \%$ danych, na część testową $15 \%$ i na część walidacyjną $15 \%$.

W kolejnym kroku wybrano (arbitralnie) typ poszukiwanej sieci (w tym przypadku MLP - multi-layer perceptron lub RBF - radial basis functions), po czym dokonano wyboru struktury badanej sieci neuronowej. Przeprowadzono to

\footnotetext{
${ }^{6}$ Opisane przez tablice zawierające czasy retencji i odpowiadające im udziały procentowe poszczególnych węglowodorów wchodzących w skład badanej benzyny silnikowej (stosunek powierzchni piku do sumy powierzchni wszystkich pików pomnożony przez 100\%).

${ }^{7}$ Takie postępowanie $z$ danymi spowoduje zmniejszenie dokładności danych wejściowych, ale wprowadzony błąd będzie błędem systematycznym, a nie przypadkowym i nie powinien zasadniczo wpłynąć na trafność prognoz i właściwości uogólniające wybranych sieci neuronowych.
} 
w następujący sposób: Po wczytaniu zbioru uczącego (powstałego z danych doświadczalnych po wyłączeniu z nich do osobnego użycia części danych traktowanych jako testowe i walidacyjne) do programu Statistica dokonano analizy tych danych przy pomocy Automatycznego projektanta sieci neuronowych. Program ten jest zbudowany w taki sposób, że $\mathrm{w}$ trakcie analizy następuje automatyczne poszukiwanie najlepszej sieci neuronowej. Założono, że Automatyczny projektant wygeneruje dużą liczbę sieci (1000), które będą uczone na podstawie posiadanych danych ze zbioru uczącego, a po weryfikacji wyników uczenia zachowanych zostanie jedynie pięć najlepszych sieci.

W celu uniknięcia ,przeuczenia” sieci przeprowadzono minimalizację liczby neuronów w warstwach ukrytych i minimalizację liczby warstw ukrytych, przy zachowaniu założonej dokładności predykcji sieci. Struktury wybranych sieci przedstawiono w tablicach 1 do 3 (w pierwszej kolumnie), a w dalszych kolumnach zamieszczono podsumowania wyników badania zbudowanych dla przewidywania wartości DVPE, E100, LOB (odpowiednio). Struktura sieci zapisywana była w postaci kodu zbudowanego z czterech elementów:

typ - liczba wejść - liczba neuronów ukrytych liczba wyjść
Ze względu na przyjęte założenia element kodu „typ” przyjmował zawsze wartość MLP, a „liczba wyjść” zawsze wynosiła 1 . Natomiast pozostałe wartości były wynikiem przeprowadzonej optymalizacji.

W kolejnych kolumnach tablic podano nazwę sieci (obejmującą jej typ MLP lub RBF oraz strukturę w układzie trzech liczb oznaczających kolejno liczbę neuronów wejściowych, liczbę neuronów ukrytych i liczbę neuronów wyjściowych), jakość sieci określoną podczas uczenia, testowania i walidacji, a także błąd popełniany przez sieć w tych samych okresach.

Analiza danych zawartych w tablicach 1-3 wskazuje, że znaleziono sieci, dla których błąd predykcji jest mniejszy od błędu oznaczania poszukiwanych nieaddytywnych parametrów opisujących jakość paliw, i tak odpowiednio:

- dla parametru DVPE są to sieci MLP 243-8-1, MLP 24324-1, MLP 243-13-1 i MLP 243-24-1, przedstawione w tablicy 1 ,

- dla parametru E100 są to sieci MLP 85-40-1 i MLP 8510-1, przedstawione $\mathrm{w}$ tablicy 2 ,

- dla parametru LOB są to sieci MLP 242-60-1, MLP 24275-1 i MLP 242-59-1, przedstawione w tablicy 3.

Dla wybranych sieci przeprowadzono analizę reszt obrazujących jakość predykcji zastosowanych rozwiązań.

Tablica 1. Podsumowanie aktywnych sieci dla predykcji prężności par DVPE

\begin{tabular}{|c|c|c|c|c|c|c|}
\hline Struktura sieci & Jakość uczenia & Jakość testowania & Jakość walidacji & Błąd uczenia & Błąd testowania & Błąd walidacji \\
\hline MLP 243-22-1 & 0,998 & 0,993 & 0,993 & 0,107 & 0,517 & 1,175 \\
\hline MLP 243-8-1 & $\mathbf{0 , 9 9 7}$ & $\mathbf{0 , 9 9 3}$ & $\mathbf{0 , 9 9 6}$ & $\mathbf{0 , 1 8 1}$ & $\mathbf{0 , 4 6 7}$ & $\mathbf{0 , 9 5 7}$ \\
\hline MLP 243-24-1 & 0,996 & 0,995 & 0,996 & 0,255 & 0,320 & 0,887 \\
\hline MLP 243-13-1 & 0,976 & 0,995 & 0,996 & 1,628 & 0,412 & 0,778 \\
\hline MLP 243-24-1 & 0,995 & 0,996 & 0,996 & 0,342 & 0,230 & 0,760 \\
\hline
\end{tabular}

Tablica 2. Podsumowanie aktywnych sieci dla predykcji wartości oddestylowania E100

\begin{tabular}{|c|c|c|c|c|c|c|}
\hline Struktura sieci & Jakość uczenia & Jakość testowania & Jakość walidacji & Błąd uczenia & Błąd testowania & Błąd walidacji \\
\hline MLP 85-40-1 & $\mathbf{0 , 9 8 3}$ & $\mathbf{0 , 8 5 8}$ & $\mathbf{0 , 9 9 4}$ & $\mathbf{0 , 3 2 5}$ & $\mathbf{2 , 0 4 0}$ & $\mathbf{0 , 0 9 7}$ \\
\hline MLP 85-31-1 & 0,982 & 0,837 & 0,994 & 0,345 & 2,295 & 0,069 \\
\hline MLP 85-28-1 & 0,984 & 0,847 & 0,993 & 0,290 & 2,210 & 0,090 \\
\hline MLP 85-10-1 & 0,981 & 0,848 & 0,994 & 0,346 & 2,151 & 0,152 \\
\hline MLP 85-31-1 & 0,982 & 0,847 & 0,993 & 0,341 & 2,229 & 0,119 \\
\hline
\end{tabular}

Tablica 3. Podsumowanie aktywnych sieci dla predykcji badawczej liczby oktanowej LOB

\begin{tabular}{|c|c|c|c|c|c|c|}
\hline Struktura sieci & Jakość uczenia & Jakość testowania & Jakość walidacji & Błąd uczenia & Błąd testowania & Błąd walidacji \\
\hline MLP 242-54-1 & 0,767 & 0,396 & 0,680 & 0,090 & 0,099 & 0,360 \\
\hline MLP 242-60-1 & 0,755 & 0,504 & 0,667 & 0,109 & 0,091 & 0,413 \\
\hline MLP 242-57-1 & 0,796 & 0,441 & 0,672 & 0,080 & 0,100 & 0,357 \\
\hline MLP 242-75-1 & 0,780 & 0,547 & 0,791 & 0,102 & 0,094 & 0,403 \\
\hline MLP 242-59-1 & $\mathbf{0 , 9 5 9}$ & $\mathbf{0 , 4 5 7}$ & $\mathbf{0 , 9 5 4}$ & $\mathbf{0 , 0 2 0}$ & $\mathbf{0 , 1 0 2}$ & $\mathbf{0 , 1 6 2}$ \\
\hline
\end{tabular}


Przykładowe dokładności predykcji sieci zamieszczono w tablicach 4-6.

Dla uzyskanych wartości przedstawionych w tablicach 4 do 6 obliczono również:

- wartość średniego błędu bezwzględnego MAE (mean absolute error), według wzoru (1):

$$
M A E=\frac{1}{m} \sum_{\tau=1}^{m}\left|y_{\tau}-y_{\tau}^{P}\right|
$$

gdzie:

$y_{\tau}$ - wartość rzeczywista (wynik badań, pomiaru),

$y_{\tau}^{P}$ - wartość przewidywana (obliczona),

$m$ - liczba prognoz wartości zmiennej;

- wartość średniego błędu predykcji ex post RMSE (root mean square error), odpowiadającego pierwiastkowi błędu średniokwadratowego, według wzoru (2):

$$
R M S E=\sqrt{\frac{1}{m} \sum_{\tau=1}^{m}\left(y_{\tau}-y_{\tau}^{P}\right)^{2}}
$$

gdzie:

$y_{\tau}$ - wartość rzeczywista (wynik badań, pomiaru),

$y_{\tau}^{P}-$ wartość przewidywana (obliczona),

$m$ - liczba prognoz wartości zmiennej.

Analiza wartości MAE i RMSE dla danych zawartych w tablicach 4 do 6 , a przedstawionych w tablicy 7 , oraz analiza wartości modułów reszt (obliczanych jako moduł różnicy między wartością będącą wynikiem badań doświadczalnych a wartością przewidywaną) wskazują, że w przebadanym

Tablica 4. Przykładowe dokładności przewidywania rozwiązań osiagniętych przy pomocy sieci neuronowych dla DVPE

\begin{tabular}{|c|c|c|c|}
\hline \multicolumn{4}{|c|}{ DVPE } \\
\hline $\begin{array}{c}\text { Wartość } \\
\text { rzeczywista }\end{array}$ & $\begin{array}{c}\text { Wartość } \\
\text { przewidywana } \\
\text { MLP 243-8-1 }\end{array}$ & Moduł reszty & $\begin{array}{c}\text { Niepewność } \\
\text { metody } \\
\text { oznaczania }\end{array}$ \\
\hline 67,0 & 68,36 & 1,36 & $\pm 1,5$ \\
\hline 69,1 & 68,35 & 0,75 & $\pm 1,5$ \\
\hline 67,0 & 68,35 & 1,35 & $\pm 1,5$ \\
\hline 62,5 & 64,03 & 1,53 & $\pm 1,5$ \\
\hline 87,0 & 88,35 & 1,35 & $\pm 1,5$ \\
\hline 63,0 & 64,39 & 1,39 & $\pm 1,5$ \\
\hline 59,9 & 61,32 & 1,42 & $\pm 1,5$ \\
\hline 66,8 & 68,35 & 1,55 & $\pm 1,5$ \\
\hline 67,8 & 68,36 & 0,56 & $\pm 1,5$ \\
\hline 78,2 & 79,32 & 1,12 & $\pm 1,5$ \\
\hline 62,4 & 61,35 & 1,05 & $\pm 1,5$ \\
\hline 56,6 & 58,04 & 1,44 & $\pm 1,5$ \\
\hline
\end{tabular}

Tablica 5. Przykładowe dokładności przewidywania rozwiązań

\begin{tabular}{|c|c|c|c|}
\hline \multicolumn{4}{|c|}{ E100 } \\
\hline $\begin{array}{l}\text { Wartość } \\
\text { rzeczywista }\end{array}$ & $\begin{array}{c}\text { Wartość } \\
\text { przewidywana } \\
\text { MLP 85-40-1 }\end{array}$ & Moduł reszty & $\begin{array}{c}\text { Niepewność } \\
\text { metody } \\
\text { oznaczania }\end{array}$ \\
\hline 56,6 & 55,13 & 1,47 & $\pm 2,1$ \\
\hline 58,1 & 55,90 & 2,20 & $\pm 2,1$ \\
\hline 58,2 & 55,96 & 2,24 & $\pm 2,1$ \\
\hline 62,4 & 60,91 & 1,49 & $\pm 2,1$ \\
\hline 62,4 & 60,90 & 1,50 & $\pm 2,1$ \\
\hline 63,6 & 65,71 & 2,11 & $\pm 2,1$ \\
\hline 51,9 & 52,90 & 1,00 & $\pm 2,1$ \\
\hline 57,4 & 55,40 & 2,00 & $\pm 2,1$ \\
\hline 56,9 & 56,82 & 0,08 & $\pm 2,1$ \\
\hline 62,1 & 59,97 & 2,13 & $\pm 2,1$ \\
\hline 61,2 & 59,40 & 1,80 & $\pm 2,1$ \\
\hline 51,5 & 52,95 & 1,45 & $\pm 2,1$ \\
\hline 53,1 & 55,13 & 2,03 & $\pm 2,1$ \\
\hline 47,2 & 45,09 & 2,11 & $\pm 2,1$ \\
\hline
\end{tabular}
osiągniętych przy pomocy sieci neuronowych dla E100

Tablica 6. Przykładowe dokładności przewidywania rozwiązań osiagniętych przy pomocy sieci neuronowych dla LOB

\begin{tabular}{|c|c|c|c|}
\hline \multicolumn{4}{|c|}{ LOB } \\
\hline $\begin{array}{c}\text { Wartość } \\
\text { rzeczywista }\end{array}$ & $\begin{array}{c}\text { Wartość } \\
\text { przewidywana } \\
\text { MLP 242-59-1 }\end{array}$ & Moduł reszty & $\begin{array}{c}\text { Niepewność } \\
\text { metody } \\
\text { oznaczania }\end{array}$ \\
\hline 95,7 & 95,95 & 0,25 & $\pm 0,4$ \\
\hline 98,8 & 98,58 & 0,22 & $\pm 0,4$ \\
\hline 95,5 & 95,53 & 0,03 & $\pm 0,4$ \\
\hline 98,9 & 98,75 & 0,15 & $\pm 0,4$ \\
\hline 96,4 & 96,84 & 0,44 & $\pm 0,4$ \\
\hline 99,4 & 99,74 & 0,34 & $\pm 0,4$ \\
\hline 95,9 & 95,42 & 0,48 & $\pm 0,4$ \\
\hline 98,5 & 98,48 & 0,02 & $\pm 0,4$ \\
\hline 95,1 & 94,96 & 0,14 & $\pm 0,4$ \\
\hline 95,4 & 95,35 & 0,05 & $\pm 0,4$ \\
\hline 96,5 & 96,48 & 0,02 & $\pm 0,4$ \\
\hline 98,8 & 98,94 & 0,14 & $\pm 0,4$ \\
\hline 96,8 & 96,95 & 0,15 & $\pm 0,4$ \\
\hline 95,2 & 95,09 & 0,11 & $\pm 0,4$ \\
\hline
\end{tabular}

zakresie dla wszystkich przewidywanych właściwości benzyn silnikowych z zawartością EETB i/lub etanolu (E100, DVPE, LOB) zastosowanie rozwiązań używających sieci neuronowych daje zadowalające wyniki dla tych sieci, w których na wejścia podawane są jako zmienne niezależne wartości intensywności pików chromatogramów benzyn 
Tablica 7. Różnica między wartością zbadaną a obliczoną dla wyników obliczeń właściwości przebadanych benzyn silnikowych z etanolem i/lub EETB

\begin{tabular}{|c|c|c|c|}
\hline $\begin{array}{c}\text { Parametry charakteryzujące } \\
\text { jakość predykcji }\end{array}$ & $|\Delta \mathrm{E} 100|$ & $|\Delta \mathrm{DVPE}|$ & $|\Delta \mathrm{LOB}|$ \\
\hline max $\mid$ odchylenie $\mid$ & 2,24 & 1,55 & 0,48 \\
\hline MAE & 1,69 & 0,11 & 0,18 \\
\hline RMSE & 1,78 & 1,28 & 0,23 \\
\hline RMSE - MAE & 0,09 & 1,17 & 0,05 \\
\hline
\end{tabular}

silnikowych otrzymanych zgodnie z normą ASTM D5134, będące podstawą do oznaczenia składu chromatograficznego badanych benzyn silnikowych.

Uzyskane modele dobrze przewidują poszukiwane właściwości benzyn, a wyniki mieszczą się w zakresie niepewności znormalizowanych metod badawczych stosowanych przy oznaczaniu tych właściwości.

\section{Wnioski}

W celu sprawdzenia hipotezy o możliwości wykorzystania sieci neuronowych do analizy danych i znajdowania w nich wiedzy przydatnej potem między innymi przy budowie systemów ekspertowych poddano badaniom 200 próbek przypadkowych mieszanek benzyny silnikowej pochodzących z rynku paliw. Nie wykonywano żadnej interpretacji wstępnej chromatogramów. Przygotowanie wstępne danych wejściowych przeprowadzono przy użyciu prostych działań (dyskryminacja i sumowanie) niewymagających docelowo wiedzy i ingerencji eksperta. W wyniku wykonanych działań i uczenia sieci powstała struktura mogąca samodzielnie przetwarzać wskazane dane, zdolna do interpretowania zależności pomiędzy składem chromatograficznym a wielkościami opisującymi nieaddytywne parametry jakościowe benzyny silnikowej (LOB, DVPE, E100). Warto podkreślić, że w rozważanych badaniach posługiwano się niezinterpretowanym przez eksperta chromatogramem, co pozwala na stosowanie stworzonego systemu do danych zbieranych przez osoby niemające własnej wiedzy na temat chromatografii, a to poszerza krąg potencjalnych użytkowników systemu. Autorzy sądzą więc, że opisane rozwiązanie, po odpowiedniej rozbudowie i dostosowaniu, może być elementem składowym systemu kognitywnej analizy i interpretacji danych dotyczących właściwości benzyn. Otrzymane wyniki są bowiem zachęcające i warte prowadzenia dalszych badań.

Prosimy cytować jako: Nafta-Gaz 2015, nr 10, s. 776-785

Artykuł nadesłano do Redakcji 14.01.2015 r. Zatwierdzono do druku 10.09.2015 r.

Artykuł powstał w wyniku badań prowadzonych w ramach projektów nr DS-051/2013 pt. Zastosowanie sieci neuronowych w badaniach nad stworzeniem komputerowego modelu nieliniowych właściwości benzyn silnikowych zawierajacych bioetanol $i$ eter etylowo-tert butylowy oraz DS-062/2014 pt. Zastosowanie sieci neuronowych w badaniach nad stworzeniem komputerowego modelu nieliniowych właściwości benzyn silnikowych zawierajacych komponenty tlenowe - praca INiG - PIB na zalecenie MNiSW.

\section{Literatura}

[1] Lula P., Paliwoda-Pekosz G., Tadeusiewicz R.: Metody sztucznej inteligencji i ich zastosowania w ekonomii i zarzadzaniu. Kraków, Wydawnictwo Akademii Ekonomicznej, 2007, ISBN 978-83-7252-357-0.

[2] Tadeusiewicz R., Chaki R., Chaki N.: Exploring Neural Networks with C\#. Boca Raton, CRC Press, Taylor \& Francis Group, 2014

[3] Tadeusiewicz R., Rutkowski L., Szaleniec M., Horzyk A., Strzelecki M.: Kompendium sieci neuronowych: dodatek. [W:] Torbicz W. i in. (red.): Sieci neuronowe w inzynierii biomedycznej.

Prof. zw. dr hab. inż. Ryszard TADEUSIEWICZ

Profesor zwyczajny

Akademia Górniczo-Hutnicza im. Stanisława Staszica w Krakowie Wydział Elektrotechniki, Automatyki, Informatyki i Inżynierii

Biomedycznej

al. Mickiewicza 30, 30-059 Kraków

E-mail:rtad@agh.edu.pl
Inżynieria Biomedyczna. Podstawy i Zastosowania. T. 9. Warszawa, EXIT, 2013, s. 667-745.

[4] Wen Yu, Xiaoou Li: Hybrid neural networks for gasoline blending system modeling. 2014 International Joint Conference on Neural Networks (IJCNN). IEEE, 2014, s. 3272-3277.

[5] Zhong Ming Luo, Zhuo Fu Liu, Fan Wang, Ling Sen Lin: Nonlinear Ethanol Gasoline Optimal Control System Based on Hammerstein Model. Advanced Materials Research 2013, vol. 765-767, s. 1889-1892.

[6] https://pixabay.com/pl/
Mgr inż. Bogusław HADUCH

Starszy specjalista badawczo-techniczny, kierownik Biura Kontroli. Instytut Nafty i Gazu - Państwowy Instytut Badawczy

ul. Lubicz 25 A

31-503 Kraków

E-mail: haduch@inig.pl 